\title{
Visual management of audiovisual projects: improving the creative process of production design
}

Juliana Krupahtz

Master's Degree, Universidade Federal de Santa Catarina / juliana.krupahtz@gmail.com Orcid: 0000-0002-5494-0116 / lattes

\section{Leandro Werner}

PhD student, Universidade Federal de Santa Catarina (UFSC) / makakowerner@gmail.com Orcid: 0000-0003-3120-7074 / lattes

Julio Monteiro Teixeira

PhD, Universidade Federal de Santa Catarina (UFSC) / juliomontex@gmail.com

$\underline{\text { lattes }}$

Sent: 08/22/2020 // Accepted: 12/12/2020 


\title{
Visual management of audiovisual projects: improving the creative process of production design
}

\begin{abstract}
The audiovisual project involves countless different professionals in actions that need to be coordinated. For these actions to be more fluid, visual project management can be used. This article aims to improve the scheme proposed by Krupahtz (2018) using visual project management. For this purpose, the areas of production design and visual project management were contextualized to make clear the interaction between them. As a methodological approach, it was used the Lemming method, by Teixeira (2018). As the result, there is the elaboration process of a visual model according to the method and it is described the creation of a visual panel that contemplates the pre-production phase, with a focus on production design. In the final considerations, it is made some suggestions for future works and presented some interesting potentials for research involving both areas.
\end{abstract}

Keywords: project visual management. Filmmaking. Production design. 


\title{
Gestão visual de projetos audiovisuais: aprimorando o processo criativo do design de produção
}

\begin{abstract}
RESUMO
O projeto audiovisual engloba inúmeros profissionais diferentes em ações que precisam ser coordenadas. Para que estas ações tenham maior fluidez, pode-se fazer uso da gestão visual de projetos. Este artigo tem como objetivo aprimorar um esquema proposto por Krupahtz (2018) utilizando a gestão visual de projetos. Para isto inicialmente foram contextualizadas as áreas de design de produção e gestão visual de projetos para tornar claro a interação entre elas e como abordagem metodológica foi utilizado o método Lemming, de Teixeira (2018). Como resultado apresenta-se o processo de elaboração de um modelo visual de acordo com o método e a criação de um painel visual que contempla a fase de pré-produção, com enfoque no design de produção audiovisual. Nas considerações finais são abordadas sugestões para trabalhos futuros e potenciais interessantes para pesquisas envolvendo as duas áreas.
\end{abstract}

Palavras-chave: gestão visual de projetos. Audiovisual. Design de produção. 


\title{
Gestión visual de proyectos audiovisuales: mejora del proceso creativo del diseño de producción
}

\begin{abstract}
RESUMEN
El proyecto audiovisual implica un sinnúmero de profesionales de diferentes acciones en que necesitan ser coordinados. Para que estas acciones sean más fluidas, se puede utilizar la gestión visual de proyectos. Este artículo tiene como objetivo mejorar un esquema propuesto por Krupahtz (2018) utilizando la gestión visual de proyectos. Para este fin, las áreas de diseño de producción y gestión de proyectos visuales fueron contextualizados para dejar en claro la interacción entre ellos y como un enfoque metodológico, el método Lemming, por Teixeira (2018), se utilizó. Como resultado, se presenta el proceso de elaboración de un modelo visual según el método y la creación de un panel visual que contempla la fase de preproducción, con foco en el diseño de producción audiovisual. En las consideraciones finales, se discuten sugerencias para trabajos futuros y potenciales interesantes para la investigación en ambas áreas.
\end{abstract}

Palabras clave: manejo visual de proyectos. Audiovisual. Diseño de producción. 


\section{INTRODUCTION}

An audiovisual project can be of many different kinds and to many different purposes, like the creation of products like movies, tv series, documentaries, video clips, artistic videos, advertising, institucional or journalistic ones. In anyone of these, especially in the ficcional ones, the creation process may be considered a creative process, that involves phases, steps and specific tasks assigned to a team project.

An audiovisual team also can be composed in many ways according to the size and complexity of the product. In ideal situations, as the coordinator of the art department is the production designer, responsible for the visual project of the movie build together with the art director.

According to the authors Grove (2004) and LoBrutto (2002), the art director function definition is to execute the project, while the production designer plans and participate of the movie conception, organizing along with the scene director, producers, director of photography and screenwriters, all the visual creation that is necessary to make the project happens.

This way, it is possible to understand that the creation process of an audiovisual project from the point of view of a production designer can be considered as a design project (KRUPAHTZ, 2018), so it is necessary a process that it is logic and easy to follow by all the crew members. Therefore, visual project management can improve the processes and the visualization of steps and tasks, especially in the most complex cases.

Visual project management can help in communication and task distribution of an audiovisual team. Its main function is to make clear, in a simpler way, relevant information when it is concerned with project development.

Another purpose that can be found in visual project 
management is to refine the communication, both among the team and the leaders with the members of the team.

This kind of management is capable of promoting the agile communication of simultaneous events that happens in a production environment (MARTINS, 2006).

This visual project arrangement is also capable of helping in the composition, planning, continuous improvement and action control, especially when there is the need of many multidisciplinary teams working together. Visual management allows a quick comprehension and visualization of the workflow, standardizing the adherence and the processes (LEAN INSTITUTE BRASIL, 2012).

In a audiovisual project, visual management can help and be like a guide to conducting the project, keeping it always connected with its main purpose.

In this research, the starting point was a descriptive board of a scheme proposed by Krupahtz (2018) that makes a cut of the audiovisual project focusing on the art department and the functions and tasks willing to be accomplished by the production designer. This model was created from the scheme of the project methodology to graphic-printed products by Matté (2004), which is originally thought for execution of design projects.

Having said that, this research has the objective to improve the systematization scheme proposed by Krupahtz (2018) using visual project management to start the elaboration of a visual model.

To accomplish this objective, initially audiovisual areas and visual project management will be contextualized to make clear the linking between both subjects. So the systematization made by Krupahtz (2018) will be introduced, this way it will be possible to analyse, contextualize and refine this model, making that it generates better results with visual 
project management tools.

\section{VISUAL MANAGEMENT AND AUDIOVISUAL}

Design process involves many kinds of activities and needs that come along to speed up the process and also to compress information with the ambition of helping in the decision making proceeding. Design area can assume pentiful shapes, as the organization of organizational structures, operational processes and not only physical products (STICKDORN E SCHNEIDER, 2014).

These processes can involve a lot of areas and teams, so there is not only one process that is ideal to all the areas, all of them are shaped accordingly the type, purpose and size of the project itself. The information and the comprehension are basic premises in all design projects, once that the information needs to be easy to understand by all the people involved (TEIXEIRA E MERINO, 2014).

To put together different processes and multidisciplinary teams can be a difficult task. Usually the process needs to be adapted to each scenario. In audiovisual, it is common the fact that the crew is composed by professionals of different areas, since audiovisual itself is not a design exclusive field of study. For this reason, the project tracking may be facilitated to all the people involved, so the project destination can be easily detectable by everyone. Moreover, the visual representations are superior in relation to the verbal ones, ending up to be more effective (BAUER E JOHNSON-LAIRD, 1993 e LARKIN E SIMON, 1987), mainly in projects which areas are focused or tangent to design.

To Teixeira (2018), the more visual the process the greater the chances of understanding and also decision making, which can let the processes be more practical and adherent to innovation. A good visualization of the information also can 
help in the learning process when it is concerned to the people involved in the project.

The actors need to have the ability to watch the process in a global way and understand the main steps, even if it is not their occupation area (TEIXEIRA, 2018). To Sibbet (2013), the teams become more efficient and effective when they are able to observe the themes and develop comparisons, localize patterns and mapping. This makes it easy to think globally about the project. In this scenario, the visual project management is capable of directing teams and promoting a better understanding by all the people involved.

Besides the integration of the actors in the same process, visual project management also allows and stimulates the cocreation during the process, "something that it is essential to the sustainability of as the users as the employees satisfaction" (STICKDORN E SCHNEIDER, 2014, p.41. Translated by the authors).

For a better understanding of visual management, it can be adopted for this article the definition by Lean Institute Brasil (2020, translated by the authors) that defines visual management as "a system of planning, controlling and continuous improvement that integrates simple visual tools that allow the understanding through a quick "look" of the current situation".

The visual project management use can make a change in the strategic planning of projects, projecting visual possibilities to all actors involved. This fact becomes an advantage because it allows a clear and transparent understanding of all actions.

The improvement of a full process understanding is also an advantage that visual management commits to deliver, especially when there is a complex flow of information in different levels of the organization (Figure 1) (TEIXEIRA, 
2018).

Figure 1. Level of disorder

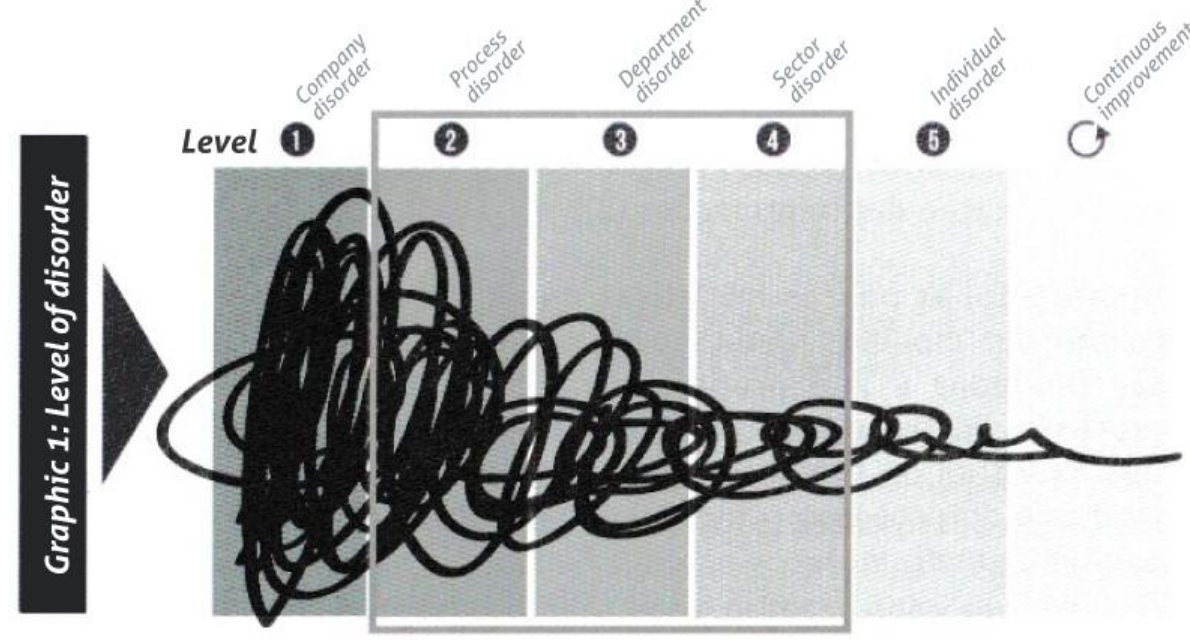

Source: TEIXEIRA (2018, p. 25). Translated by the authors.

In the graphic above it is possible to notice the complexities found in processes that involve complex teams from different places of the company. With this issue of comprehension the process may be disturbed by conflits based in misunderstandment, communication flaws, misinterpretation, frustration and disagreements (TEIXEIRA, 2018).

In a complex system where significant assets are involved, as in an audiovisual production, where there are many areas and different people that need to coordinate efforts in sync, visual management can be the flagship to guide the process during its execution. Visual management will allow quick system comprehension and information discovery (DUSSE et al, 2016). There is not an only way to use visual management, because it is a tool that is also dynamic and adaptable to many models and other methodologies. Teixeira (2018) proposes a model, suggesting a system based on visual representations for better management practice, mentioning premises and functions that should be part of visual project management. Among these, it can be highlighted the use of visual panels that do not seek to detail 
each aspect of the model, but to provide a general view. The author also mentions what can be used as a source of information, including colors, fonts and shapes, even textual and numerical elements. In the end, it is proposed a roadmap with guidelines for the construction of a visual model that will serve as a support for visual management.

\subsection{Lemming method}

So for the studies of the present paper, it was chosen to use the structure method of Lemming proposed by Teixeira (2018). This method also will serve as a methodological procedure to support the research. According to the author, it helps visual management to develop different kinds of projects.

This method is also characterized by being "a proposal that aims to disseminate principles, values and tools that advocate the visualization of information and visual thinking" (WERNKE, 2017, p.54. Translated by the authors).

In his structure proposal, Teixeira (2018) describes some premisses to visual project management (Figure 2), as: to prioritize process visualization, to develop visual strategies that can be applied since the planning, to elaborate action plans based on diagrams, to have visualization alternatives, to value visual analysis, and to promote interaction and participation of the whole team. 
Figure 2. Lemming premises

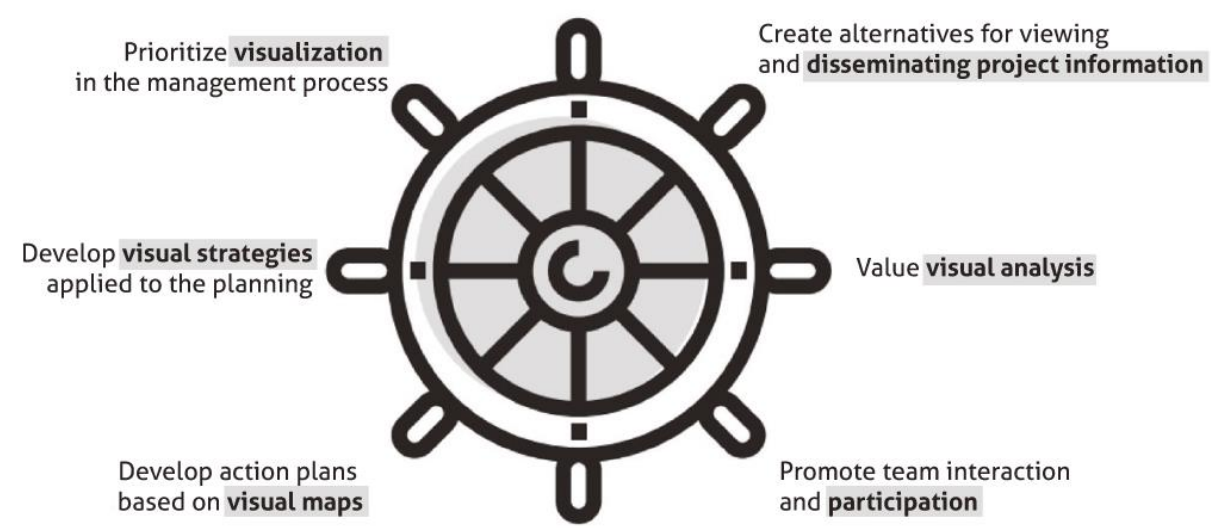

Fonte: Wernke (2017, p.54). Translated by the authors.

Lemming method is composed of five steps called sprints, and developed to suit numerous projects, especially in the design area. In the figure below (Figure 3) it can be seen that in each stage the higher the degree of the project's overview, the smaller the specific details of each stage. The smaller the overall view, the greater the level of detail for each stage.

Figure 3. Visual project management tools Promote visualization

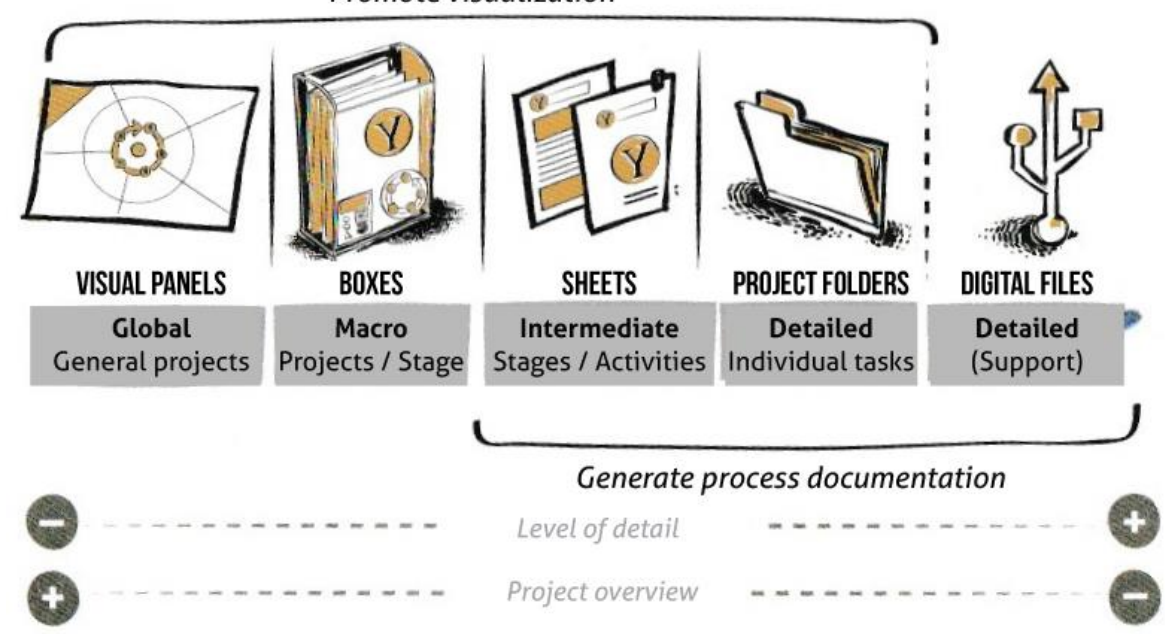

Source: TEIXEIRA (2018, p. 103). Translated by the authors.

In the initial stage - Descriptive Table - it is necessary to select a reference model and to create based on the description of steps in a detailed way. It becomes possible, for example, to use central questions, such as (i) what?, (ii) why? 
and (iii) how? to do it, so that they build a visual model and fill in a step board.

In sprint 1 - Step Board - a chart is made to describe the steps of the process at different levels of complexity (WERNKE, 2017). These different levels can go from global, through intermediate and detailed (TEIXEIRA, 2018).

In sprint 2 - Visual Thinking - the analysis of the visual tools that will be used in the project will begin. In this stage, visual management is incorporated as a way of making each stage more visual, as well as the project boxes containing the guidance sheets for each stage. The guidance sheets are intended to help the understanding of all the activities that will be developed.

It is also the step where it happens the construction of a visual panel, which the main function is to stimulate the teams to promote interaction with the model and the project, expressing in a simple way the information to all the members. These panels can still be of different kinds like: (a) fixed; (b) movable; (c) team; (d) activities; (e) visual schedule and; ( $f$ ) message card. Each one with its best interaction, should be used according to priority and best interaction to each project.

In step sprint 3 - Detailing Tools - project folders are used, which are a practice for storing physical documents. They contain the guidance sheets and also the output sheets, which must be completed at the end of each step, with the purpose of promoting a visual synthesis for the next stage.

Last step, sprint 4 - Prototyping and Implementation they become resources to support management, they must always be updated and shared among team members in detail. Therefore, it is understood that the best way to perform this step is through the use of digital files. 
Figure 4. Roadmap to a visual model

\section{ROADMAP TO A VISUAL MODEL}

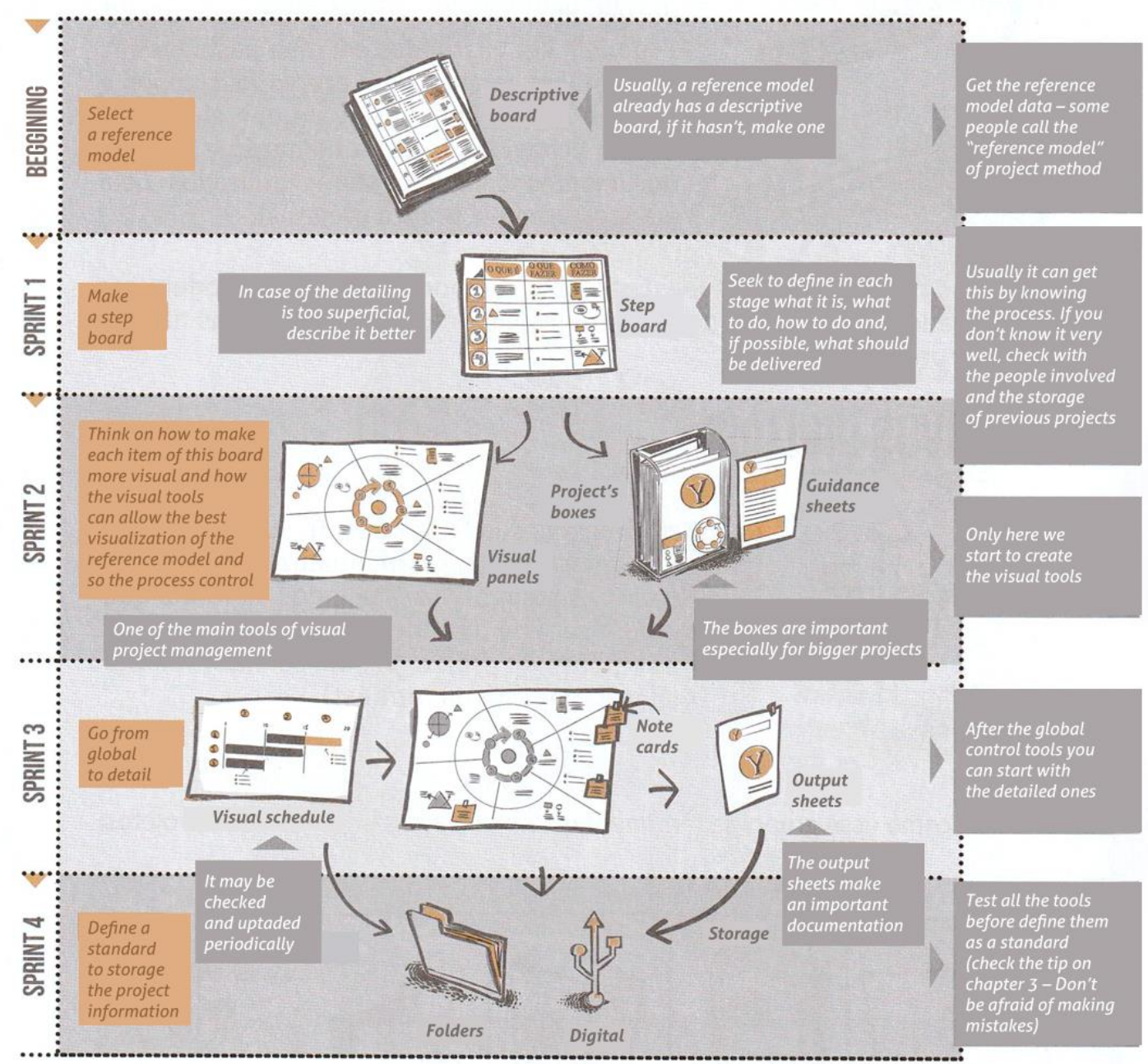

Source: TEIXEIRA (2018, p. 104). Translated by the authors.

In the figure above there is a visual model of Lemming method to visual project management. Teixeira (2018) still alerts to the need of prototyping and adapting the model according to each demand, always valuing the best interaction and usability with users.

\subsection{The audiovisual project from the perspective of the production designer}


Production design is the area of audiovisual and cinema responsible for the visual composition of the movie, including the disposition of sets, furniture and props and their relations with the actors (BAPTISTA, 2008). The production designer is the professional in charge of coordinating the art department, including the creation, execution and coherence of the project.

Considering the points brought in the previous section, it is understood that visual management can collaborate in a meaningful way to a better comprehension and visualization of the entire creative process, especially in the cases with large teams.

In the beginning of an audiovisual project, the first stage is the pre-production. In it, the first ideas will start to be validated and it is organized everything that will be necessary to the next stage, which would be the production, or, the footage.

The better the work made in this period of the project, the better will be the rest of the project. In a general way, besides the creation or approval of a script already written, it is also organized the budget, definition of team members, search for possible locations, casting, legal aspects (documentations, contracts, equipment insurances), footage schedule, renting/definition of equipment, among others. In this phase also happens the creation of the visual concept of the movie. Because of that, this is the phase that is more similar to the design creative process in the same time that should be carefully planned and executed, so the chances of redoing the work and loss can be minimized.

The systematization scheme made by Krupahtz (2018) was built with focus on audiovisual projects from the perspective of the production designer and the team from the art department, based in the methodology to graphic-printed 
projects by Matté (2004), to the phase of pre-production. The complete model still includes the production and post production phases in a simplified way, however, to this research, it was chosen to work only with the pre-production phase (Figure 5), because it is the phase with the greatest creative proposal.

Figure 5. Pre-production systematization

\begin{tabular}{|c|c|c|c|c|c|}
\hline & \multirow[t]{2}{*}{ PHASES } & \multirow{2}{*}{$\begin{array}{l}\text { STAGES } \\
\text { PROBLEMATIZATION }\end{array}$} & \multirow{2}{*}{$\begin{array}{l}\text { ACTIVITIES } \\
\text { PROBLEM EKPOSURE } \\
\text { PROGRAM }\end{array}$} & \multirow{2}{*}{$\begin{array}{l}\text { TASKS } \\
\text { RECEIVE STORY LINE } \\
\text { AND SCRIPT } \\
\text { DECOUP, PLAN } \\
\text { SCHEDULE AND TEAM }\end{array}$} & \multirow{2}{*}{$\begin{array}{l}\text { DOCUMENTS } \\
\text { CHECKLIST: } \\
\text { CASTING, COSTUME, } \\
\text { LOCATIONS } \\
\text { AND PROPS }\end{array}$} \\
\hline & & & & & \\
\hline & \multirow[t]{2}{*}{$\begin{array}{l}\text { PROJECT } \\
\text { COMPR. }\end{array}$} & RESEARCH & $\begin{array}{l}\text { DIACHRONIC } \\
\text { AND SYNCHRONIC } \\
\text { MARKET ASPECTS }\end{array}$ & $\begin{array}{l}\text { SEARCH REFERENCES, } \\
\text { THEME/SUBJECT, HISTORY } \\
\text { INVESTIGATE PUBLIC } \\
\text { AND MEDIA }\end{array}$ & CHARACTERS MAP \\
\hline $\begin{array}{l}P \\
R \\
E\end{array}$ & & ANALYSIS & $\begin{array}{l}\text { FORMAL AND } \\
\text { INFORMATIONAL }\end{array}$ & $\begin{array}{l}\text { ANALYSE COLOR, CHARACTERS, } \\
\text { COSTUMES, PLACES, PROPS, } \\
\text { GRAPHIC DESIGN, AND } \\
\text { PROMOTION MATERIAL }\end{array}$ & \\
\hline $\begin{array}{l}P \\
R \\
O \\
D\end{array}$ & \multirow[t]{2}{*}{$\begin{array}{l}\text { PROJECT } \\
\text { CONFIG. }\end{array}$} & DEFINITION & $\begin{array}{l}\text { REQUIREMENTS LIST } \\
\text { PROBLEM } \\
\text { REDEFINITION }\end{array}$ & $\begin{array}{l}\text { DEFINE MANDATORY, } \\
\text { DESIRABLE AND OPTIONAL } \\
\text { SKETCH WITH TEXTS, } \\
\text { SCHEMES, AND DIAGRAMS } \\
\text { DESIGN STORYBOARD }\end{array}$ & BUDGET LIST \\
\hline $\begin{array}{l}\mathrm{C} \\
\mathrm{T} \\
\mathrm{I}\end{array}$ & & $\begin{array}{l}\text { INITIAL } \\
\text { MODELING }\end{array}$ & $\begin{array}{l}\text { SCOUTING } \\
\text { INITIAL / } \\
\text { INTERMEDIATE MODELS }\end{array}$ & $\begin{array}{l}\text { SCOUT LOCATIONS, COSTUMES, } \\
\text { PROPS AND CAST } \\
\text { MAKE INITIAL PRESENTATION }\end{array}$ & \\
\hline$N$ & \multirow[t]{2}{*}{$\begin{array}{l}\text { PROJECT } \\
\text { REALIZATION }\end{array}$} & $\begin{array}{l}\text { FINAL } \\
\text { MODELING }\end{array}$ & FINAL MODELS & RECORD ANIMATIC & \\
\hline & & STANDARDIZATION & $\begin{array}{l}\text { CODING FOR } \\
\text { PRODUCTION } \\
\text { TECHNICAL } \\
\text { DESCRIPTION } \\
\text { OF PRODUCTION }\end{array}$ & $\begin{array}{l}\text { MAKE FINAL PRESENTATION } \\
\text { FORWARD FOR PURCHASE } \\
\text { OR PRODUCTION OF ART }\end{array}$ & $\begin{array}{l}\text { CREDITS LIST, } \\
\text { CHECKLIST: } \\
\text { PRE-SHOOT }\end{array}$ \\
\hline
\end{tabular}

Source: KRUPAHTZ (2018, p. 55). Translated by the authors.

The presented scheme by the author as an "Activities, tasks and documents systematization to audiovisual project" uses as a base the methodologies by Matté (2004) and Rodrigues (2007), respectively to the structure of production and post production. It is believed that this proposal can be improved if built with the principles of visual project management. So, the board of Figure 5 was chosen to represent the descriptive board of the initial step of Lemming 
method, then it was developed a step board and then, a visual panel.

\section{RESULTS}

The construction of this visual panel can be understood as a new artifact to the solution of the proposed objective. Gill and Hevner (2011, p. 238. Translated by the authors) define artifacts as "[...] a symbolic representation or a physical instantiation of design concepts.". Such an artifact has its fundamental base anchored in Design Science Research, once that this method suggests that the researcher may explore many artifacts and then build something new or use an already existing artifact (DRESCH; LACERDA; ANTUNES JUNIOR, 2015).

To the development of this solution, it was chosen to create a new artifact as a support to an existing method - the Lemming method. This visual panel can be classified as an artifact of method. This classification, according to Desch, Lacerda e Antunes Junior (2015) refers to the group of necessary steps to achieve a task. Such steps, or stages, can have graphic representation or be involved in specific heuristics and algorithms (DRESCH; LACERDA; ANTUNES JUNIOR, 2015, p. 112).

In the construction of an artifact, Gill and Hevner (2011) suggests some layers to this process. In the first layers is found the design space, that is the analysis of "possible solutions to the problem, that is, the possible artifacts to be developed, as well as the requirements for their proper functioning." (DRESCH; LACERDA; ANTUNES JUNIOR, 2015, p.109. Translated by the authors).

After choosing the solution, the second layer, called the development of the artifact, is applied. This is properly the construction of the artifact and can be subdivided into: 
viability, utility, representation, and artifact construction (DRESCH; LACERDA; ANTUNES JUNIOR, 2015).

In the last layer, there is the use of the artifact that "seeks to prepare it for its implementation and use in a real environment" (DRESCH; LACERDA; ANTUNES JUNIOR, 2015, p.109. Translated by the authors). This last layer is also subdivided in "pilot instantiation of the artifact and release of the artifact for instantiation" (DRESCH; LACERDA; ANTUNES JUNIOR, 2015, p.109. Translated by the authors). The construction of the visual panel (artifact) focuses mainly on the second layer, called development of the artifact.

According to the Lemming method, in the beginning of the process of the construction of a visual model, as it was mentioned in the previous section, there is the Descriptive Board, graphic represented by Krupahtz (2018) in Figure 5. In the board it is possible to observe some information as phases, stage, activities, tasks and documents. To the construction of step board (Table 1) - sprint 1 - those information were rewritten, detailed and reorganized accordingly the following categories: (i) phase, (ii) stage, (iii)what it is, (iv) what to do, (v) how to do, and still (vi) what to deliver. The last category was added as a way to better organize the construction of future output sheets to each stage of the project, what is suggested by Teixeira (2018), instead grouping in documents, as it was made in the original board. In this table, the stages were organized by colors according to each phase of the project, to make it easier the construction of the visual panel. 
Table 1. step board

\begin{tabular}{|c|c|c|c|c|c|}
\hline PHASE & STAGE & WHAT IT IS & WHAT TO DO & HOW TO DO & WHAT TO DELIVER \\
\hline & \multirow[t]{5}{*}{$\begin{array}{l}1 . \\
\text { Problematization }\end{array}$} & $\begin{array}{l}\text { 1A. Problem } \\
\text { Exposure }\end{array}$ & $\begin{array}{l}\text { Receive story line and } \\
\text { script }\end{array}$ & Provide a printed script with the core team & Printed script \\
\hline & & \multirow[t]{4}{*}{ 1B. Program } & Decoup the script & $\begin{array}{l}\text { Highlight the points that identify visual } \\
\text { characteristics of the film, such as costumes, } \\
\text { environments, character aspects, props, } \\
\text { among others }\end{array}$ & Printed script after decoupage \\
\hline & & & Fill checklist & $\begin{array}{l}\text { Identify elements extracted from the script } \\
\text { decoupage process }\end{array}$ & Filled in checklist \\
\hline & & & Plan the schedule & Fill in visual schedule and attach to panel & Filled in schedule \\
\hline & & & Organize the crew & Hire crew and distribute functions & $\begin{array}{l}\text { List with name of crew members } \\
\text { and their respective functions }\end{array}$ \\
\hline \multirow{11}{*}{ 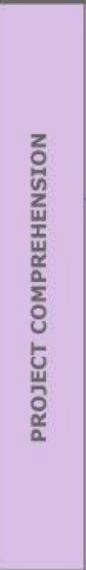 } & \multirow[t]{4}{*}{ 2. Research } & \multirow{3}{*}{$\begin{array}{l}\text { 2A. Diachronic } \\
\text { and Synchronic }\end{array}$} & Research references & \multirow{3}{*}{$\begin{array}{l}\text { Group collected information and image in a } \\
\text { single document, which can be a mood board } \\
\text { displayed in a work room, along with the visual } \\
\text { panel }\end{array}$} & \multirow{3}{*}{$\begin{array}{l}\text { Visual references mood board with } \\
\text { notes on subjects and historical } \\
\text { context covered by the script }\end{array}$} \\
\hline & & & $\begin{array}{l}\text { Research themes/subjects } \\
\text { involved }\end{array}$ & & \\
\hline & & & Research historical context & & \\
\hline & & $\begin{array}{l}\text { 2B. Market } \\
\text { Aspects }\end{array}$ & $\begin{array}{l}\text { Investigate public and } \\
\text { media }\end{array}$ & $\begin{array}{l}\text { Generate a market report and which platforms } \\
\text { will be used for promotion }\end{array}$ & Market and media report \\
\hline & \multirow[t]{7}{*}{ 3. Analysis } & \multirow{7}{*}{$\begin{array}{l}\text { 3A. Formal and } \\
\text { Informational }\end{array}$} & Analyze color & \multirow{6}{*}{$\begin{array}{l}\text { Sort a sample of the main reference works, } \\
\text { raised in the research stage and analyze each } \\
\text { of the listed aspects. Finally, unify everyone on } \\
\text { the output sheet. }\end{array}$} & \multirow{6}{*}{$\begin{array}{l}\text { Analysis of the selected work's } \\
\text { elements }\end{array}$} \\
\hline & & & Analyze characters & & \\
\hline & & & Analyze costumes & & \\
\hline & & & Analyze locations & & \\
\hline & & & Analyze graphic design & & \\
\hline & & & $\begin{array}{l}\text { Analyze promotional } \\
\text { material }\end{array}$ & & \\
\hline & & & Fill character map & $\begin{array}{l}\text { Based on the references, fill out a character } \\
\text { map file with characteristics, attaching images } \\
\text { as a reference, which can be sketches or } \\
\text { figures. }\end{array}$ & $\begin{array}{l}\text { Filled character map, with images } \\
\text { and sketches attached }\end{array}$ \\
\hline \multirow{8}{*}{ 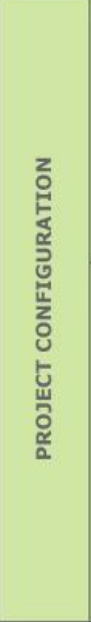 } & \multirow[t]{4}{*}{ 4. Definition } & \multirow[t]{2}{*}{$\begin{array}{l}\text { 4A. Requirements } \\
\text { List }\end{array}$} & $\begin{array}{l}\text { Define mandatory, } \\
\text { desirable and optional } \\
\text { requirements }\end{array}$ & $\begin{array}{l}\text { Complete list of requirements according to the } \\
\text { possibilities and limitations of the project }\end{array}$ & Filled requirements list \\
\hline & & & Define expenses & Start filling out the expense forecast list & Expense list filled \\
\hline & & \multirow[t]{2}{*}{$\begin{array}{l}\text { 4B. Problem } \\
\text { redefinition }\end{array}$} & $\begin{array}{l}\text { Sketch with texts, } \\
\text { schemes, and diagrams }\end{array}$ & $\begin{array}{l}\text { Put the ideas on paper, if necessary print and } \\
\text { group visual references collected in step } 2 \text {. }\end{array}$ & Film concept sketches and notes \\
\hline & & & Build storyboard & $\begin{array}{l}\text { Use storyboard sheet to sketch frames and } \\
\text { visualizations of physical aspects of the } \\
\text { footage }\end{array}$ & Storyboard \\
\hline & \multirow[t]{4}{*}{$\begin{array}{l}\text { 5. Initial } \\
\text { Modeling }\end{array}$} & \multirow[t]{3}{*}{ 5A. Scouting } & Scout location & $\begin{array}{l}\text { Based on references, catalog and record } \\
\text { possible locations }\end{array}$ & $\begin{array}{l}\text { List of locations with photos, } \\
\text { addresses, prices, contacts, } \\
\text { advantages, and disadvantages }\end{array}$ \\
\hline & & & Scout costumes and props & $\begin{array}{l}\text { Acquire pieces, sketch costumes that need to } \\
\text { be produced, and make partnerships with } \\
\text { suppliers }\end{array}$ & $\begin{array}{l}\text { Sketches of costumes and contacts } \\
\text { of partnerships made }\end{array}$ \\
\hline & & & Casting & $\begin{array}{l}\text { Follow casting tests performed by the casting } \\
\text { department and check if they meet the } \\
\text { requirements defined for the characters }\end{array}$ & $\begin{array}{l}\text { Names and photos of hired actors. } \\
\text { Note costume measurements on } \\
\text { the initial checklist sheet }\end{array}$ \\
\hline & & $\begin{array}{l}\text { 5B. Initial / } \\
\text { intermediate } \\
\text { models }\end{array}$ & Make initial presentation & $\begin{array}{l}\text { Group all the generated documentation and } \\
\text { present the concept to the core team. } \\
\text { Document necessary changes and pass on } \\
\text { reports to production }\end{array}$ & Cataloged project documentation \\
\hline \multirow{5}{*}{ 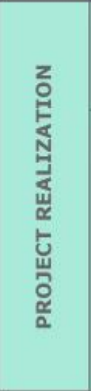 } & 6. Final modeling & 6A. Final models & Record animatic & $\begin{array}{l}\text { Shoot in the locations already chosen, with the } \\
\text { cast either hired or not, with simplified } \\
\text { equipment, to test framings and list possible } \\
\text { visual changes }\end{array}$ & Animatic \\
\hline & \multirow[t]{4}{*}{$\begin{array}{l}7 . \\
\text { Standardization }\end{array}$} & $\begin{array}{l}\text { 7A. Coding for } \\
\text { production }\end{array}$ & Make final presentation & $\begin{array}{l}\text { Group documentation with changes and } \\
\text { animatic to present a new concept to the team }\end{array}$ & Updated project documentation \\
\hline & & \multirow[t]{3}{*}{$\begin{array}{l}\text { 7B. Technical } \\
\text { description of } \\
\text { production }\end{array}$} & $\begin{array}{l}\text { Forward for purchase or } \\
\text { production of art }\end{array}$ & $\begin{array}{l}\text { Delegate purchase or art production tasks of } \\
\text { all listed items for production }\end{array}$ & $\begin{array}{l}\text { List of responsible for each task } \\
\text { and list of items already acquired } \\
\text { or produced }\end{array}$ \\
\hline & & & Fill credit list & $\begin{array}{l}\text { Register partnerships, professionals involved, } \\
\text { volunteers and team involved in the project }\end{array}$ & Filled credit list \\
\hline & & & Fill in pre-shoot checklist & $\begin{array}{l}\text { Organize necessary items according to the } \\
\text { production schedule and store properly for } \\
\text { transportation }\end{array}$ & $\begin{array}{l}\text { Pre-shoot checklist completed and } \\
\text { items arranged for production }\end{array}$ \\
\hline
\end{tabular}

Source: Authors (2020).

In sprint 2, the visual tools are created. They can be visual panels, boxes, sheets, among others previously mentioned. For this article, it was chosen to design a visual panel (Figure 
6) that can be used as a team panel or a fixed panel. It promotes a wider visualization of all tasks that must be executed in pre-production phase and uses the same colors and information already described in the step board, however organized in a visual way and in a radial structure.

Figure 6. Visual panel of pre-production
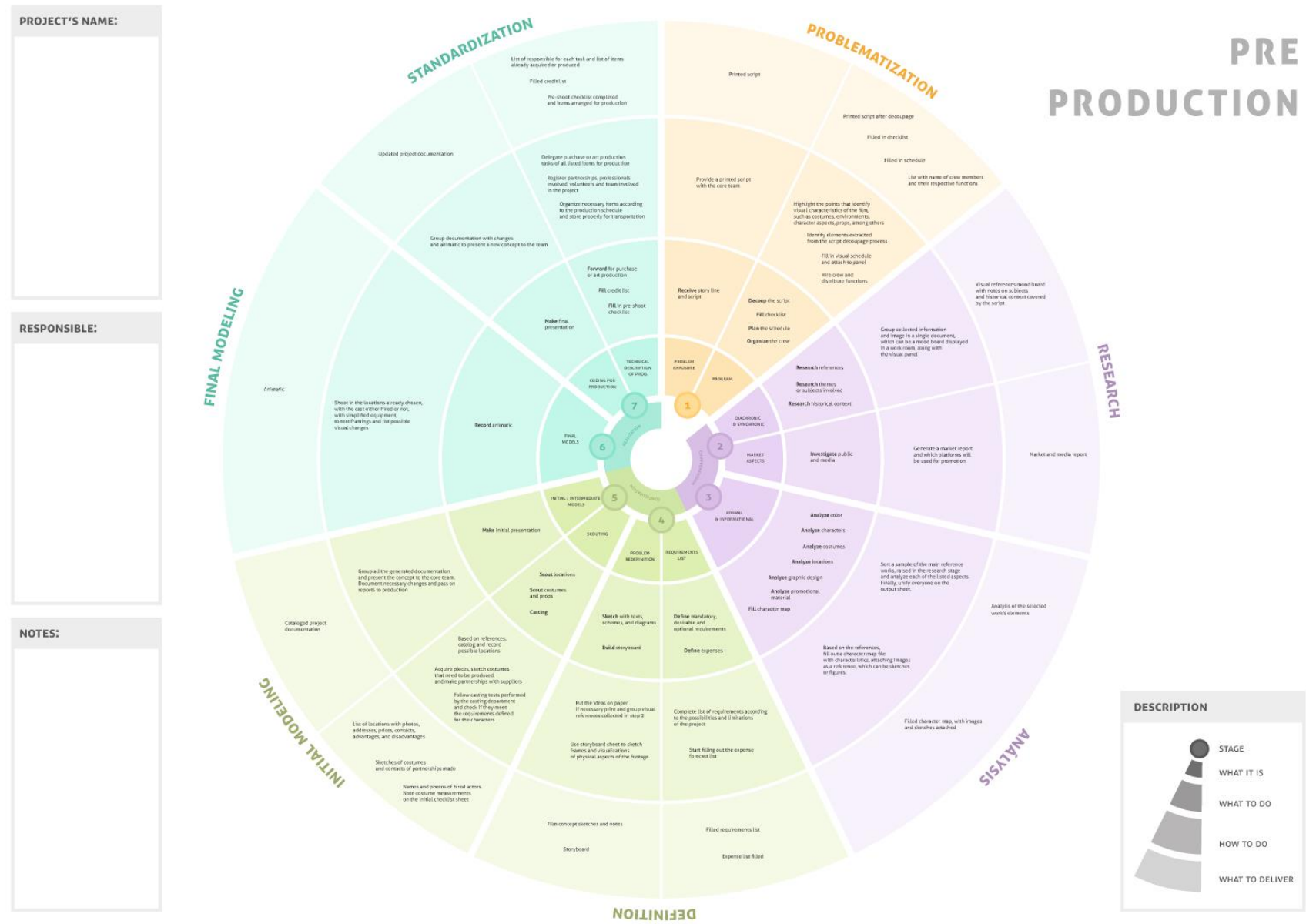

Source: Authors (2020).

With all the phases, stages and tasks described in only one visual scheme, the information becomes accessible simultaneously to all team members. In the case of using a fixed panel, the paper sheet can be printed and made available in the workplace, this way the professionals can interact with it graphicly, adding notes and checking tasks when they are done.

It was decided that the visual panel would be diagrammed 
in a paper sheet size $A 2$, that can be easily printed in many print shops. If the panel were used as a team panel, it can be printed in a smaller size to become more portable. This way, the professionals when in the locations during footage can track the tasks until the end of all of them.

In the sheet, besides the image of the visual panel, there are also some fields to be completed manually with the name of the project, the person responsible for it - it understood that this person should be the production designer - and to make some notes. In the inferior right corner it was made a description of how the categories were organized to promote a better comprehension of the graphic.

\section{FINAL CONSIDERATIONS}

Although the scheme proposed by Krupahtz (2018) isn't characterized as a methodology itself, but a systematization made from an adaption of others methodologies, it is possible to realize the improvement of the art department creative process visualization and production design of all the preproduction phase. It is believed that with more works approaching the same theme and with the continuous application of other visual project management tools in this same model it can be improved and evolve as a whole, including the phases of production and post production.

Design Science Research can be used as an auxiliary element of the result process, having greater influence on the artifact construction and its systematization, to generate a solution for the proposed objective. With the use of Design Science Research heuristics, it was possible to find a desirable solution that could be validated later. It is recommended that for future works, the use of Design Science Research in the other layers of construction is maintained. This way, it will also assist in future validation processes with users of this 
panel and other tools that can be created.

For these tools, it is believed that would improve the user experience of the panel with the construction of guidance and output sheets for each one of the project stages, so important tools can be generated to record all the material produced during the project. Therefore as a proposal for future works, it is suggested that beyond the creation of these tools, that their designs specify the sectors of the art department, such as costume, make up and set, since the model image was build to possibilitate the process visualization of all team, not only the production designer view.

As a way to make this future creation work easier, this research was concerned with pointing out the results of each stage with the category "what to deliver" that appears in both the step board and the visual panel. It is believed that the union of the elements described in this category in a single output sheet for each stage can be the better way to design this tool, so the storage of documents and their delivery to the production team can be facilitated.

In addition to the purpose of this article, the construction of methodologies created from the concepts of visual project management, however specifically designed for audiovisual products, can be of great value to design professionals, especially if these researches focus on production design and the art department, a sector of the audiovisual team that has great affinity in terms of the creative process with design.

In this way, with an increasing number of researches based on this theme, it is expected to stimulate the presence of design professionals occupying these spaces in the audiovisual market. 


\section{REFERENCES}

BAPTISTA, M. A pesquisa sobre design e cinema: o design de produção. Revista Galáxia, 2008. v. 15, p. 109-120. Disponível em:

http://revistas.pucsp.br/index.php/galaxia/article/viewFile/1498/9 70.

BAUER, Malcolm; JOHNSON-LAIRD, Philip. (1993). How diagrams can improve reasoning. Psychological Science, v.4, n.6, p.372-378, nov. $1993 . \quad$ Disponível em: https://www.jstor.org/stable/40062565?seq=1. Acesso em: 14 ago. 2020.

DUSSE, Flávio; JÚNIOR, Paulo Simões; ALVES, Antonia Tamires; NOVAIS, Renato; VIEIRA, Vaninha; MENDONÇA, Manoel. Information visualization for emergency management: A systematic mapping study. Expert Systems with Applications, 45(1), p.424437. Disponível em: https://www.researchgate.net/publication/284017230_Information _visualization_for_emergency_management_A_systematic_mappi ng_study. Acesso em: 14 ago. 2020.

DRESCH, Aline; LACERDA, Daniel Pacheco; ANTUNES JUNIOR, José Antonio Valle. Design science research: método de pesquisa para avanço da ciência e tecnologia. Porto Alegre: Bookman, 2015. Epub.

GROVE, Elliot. Raindance producers' lab: lo-to-no budget filmmaking. Burlington, MA: Focal Press, 2004.

KRUPAHTZ, Juliana. O Design no Audiovisual: o papel do designer de produção no desenvolvimento de videoclipes. 2018. TCC (Graduação) - Curso de Desenho Industrial, Departamento de Desenho Industrial, Universidade Federal de Santa Maria, Santa Maria, 2018.

LARKIN, Jill; SIMON, Herbert. (1987). Why a diagram is (sometimes) worth ten thousand words. Cognitive Science, v.11, n.1, p.65-100, mar. 1987. Disponível em: https://onlinelibrary.wiley.com/doi/abs/10.1111/j.15516708.1987.tb00863.x. Acesso em: 14 ago. 2020.

LEAN INSTITUTE BRASIL. Gestão Visual para apoiar o trabalho
padrão das lideranças. https://www.lean.org.br/colunas/366/gestao-visual-para-apoiar-otrabalhopadrao-dasliderancas.aspx. Acesso em: 6 ago. 2020.

LOBRUTTO, Vincent. The filmmaker's guide to production design. Nova Iorque: Allworth Press, 2002.

MARTINS, Flavio Eduardo. Diretrizes para o desenvolvimento de dispositivos visuais em linhas de produção enxuta no setor automotivo. Dissertação (Mestrado). Universidade Federal do Paraná, Curitiba, 2006.

MATTÉ, Volnei. Proposta de metodologia projetual para produtos gráfico-impressos. Expressão. v.1, n.1, p.60-66, jul. 2004.

RODRIGUES, Chris. 0 cinema e a produção. 3 ed. Rio de Janeiro: 
Lamparina Editora, 2007.

STICKDORN, Marc; SCHNEIDER, Jakob. Isto é Design Thinking de Serviços: fundamentos, ferramentas, casos. Porto Alegre: Bookman, 2014.

TEIXEIRA, Júlio Monteiro. Gestão visual de projetos: utilizando a informação para inovar. Rio de Janeiro: Alta Books, 2018.

TEIXEIRA, Júlio Monteiro et al. Gestão Visual: uma proposta de modelo para facilitar o processo de desenvolvimento de produtos. Idemi: Conferência Internacional De Design, Engenharia e Gestão Para a Inovação. p. 01-09. Anais. Florianópolis: Idemi, 2012. Disponível em: http://juliomontex.com.br/wpcontent/uploads/2013/04/IDEMi_2012_Gestao_Visual.pdf. Acesso em: 10 ago. 2020.

WERNKE, Débora Verones. O Desenvolvimento de um Conjunto de Ferramentas Visuais para a Gestão de Projetos: um estudo de caso na empresa Bradda Design. 2012. 99 f. TCC (Graduação) Curso de Design, Centro de Comunicação e Expressão, Universidade Federal de Santa Catarina, Florianópolis, 2017. Disponível em: https://repositorio.ufsc.br/handle/123456789/192852. Acesso em: 12 ago. 2020. 